PERM JOURNAL OF PETROLEUM AND MINING ENGINEERING

ВЕСТНИК ПНИПУ. ГЕОЛОГИЯ. НЕФТЕГАЗОВОЕ И ГОРНОЕ ДЕЛО

ISSN 2224-9923

Volume / Tом 16 №4 2017

http://vestnik pstu.ru/geo/

УДК 552.578.2.061.4:553.26

Article / Статья

(C) PNRPU / ПНИПУ, 2017

\title{
STUDY OF ZONES OF WETTABILITY DISTRIBUTION BASED ON LATERAL LOGGING FOR OIL-BEARING VISEAN RESERVOIRS OF THE SOLIKAMSK DEPRESSION
}

\author{
Igor Yu. Kolychev
}

Perm National Research Polytechnic University (29 Komsomolskiy av., Perm, Russian Federation, 614990)

\section{ИЗУЧЕНИЕ ЗОНАЛЬНОСТИ РАСПРЕДЕЛЕНИЯ ПОКАЗАТЕЛЕЙ СМАЧИВАЕМОСТИ ПО ДАННЫМ БОКОВОГО КАРОТАЖА ДЛЯ НЕФТЕНАСЫЩЕННЫХ ВИЗЕЙСКИХ КОЛЛЕКТОРОВ СОЛИКАМСКОЙ ДЕПРЕССИИ}

\section{И.Ю. Колычев}

Пермский национальный исследовательский политехнический университет (614990, Россия, г. Пермь, Комсомольский пр., 29)

Received / Получена: 15.09.2017. Accepted / Принята: 12.10.2017. Published / Опубликована: 01.02.2017

\section{Key words:}

specific electrical resistance, lateral logging, well logging, wettability, hydrophilic reservoir, hydrophobic reservoir, core, pore space structure.

\begin{abstract}
The relationship between well electrometry data and wettability of Visean clastic reservoirs of the Solikamsk depression was studied. Results of lateral logging with conventional and special core analysis are compared. Theoretical aspects of the influence of reservoir properties, characteristics of the pore space structure and wettability on electrical conductivity is considered. Theoretical calculations of the range of variation of the specific electrical resistance in the conditions of clastic reservoirs of various types are performed. The significant influence of wettability index of surface rocks on the rock resistance is substantiated.

The analysis and comparison of different methods for assessing the wettability of rocks from core data are performed. It was found that the greatest errors in rock wettability assessments are associated with hydrophilization of the surface due to core extraction. It is concluded that the X-ray core tomography as a direct method for visualization of pore space in assessing the wettability of operational objects is a perspective method.

As a result of generalization of core studies and considered analysis of the development history the geological section with anomalously high specific electrical resistances (200 $\Omega \mathrm{m}$ and above) is interpreted as predominantly hydrophobic. A section with standard resistance values for clastic reservoirs (less than $120 \Omega \mathrm{m}$ ) is classified as a hydrophilic type As a result of generalization of core studies and considered analysis of the development history the geological section with anomalously high specific electric resistances (200 $\Omega \mathrm{m}$ and above) is interpreted as predominantly hydrophobic. A section with standard resistance values for clastic reservoirs (less than $120 \mathrm{Ohm} \cdot \mathrm{m}$ ) is classified as a hydrophilic type. For the Visean reservoirs ( $\mathrm{Tl}, \mathrm{Bb}, \mathrm{Ml}$ ) of the Shershnevskoye oil field zonation on distribution of reservoirs of various wettability types is carried out on the basis of resistance values. Schemes of distribution of hydrophilic and hydrophobic reservoirs for the Visean operational reservoirs of the Solikamsk depression can be used to develop design solutions for both production and injection wells.
\end{abstract}

Ключевые слова: удельное электрическое сопротивление, боковой каротаж, геофизические исследования скважин, смачиваемость, гидрофильный коллектор, гидрофобный коллектор, керн, структура порового пространства.

\begin{abstract}
Изучена взаимосвязь данных электрометрии скважин со смачиваемостью терригенных коллекторов визейского возраста Соликамской депрессии. Проведено сопоставление результатов бокового каротажа со стандартными и специальными исследованиями керна. Рассмотрены теоретические аспекты влияния на электрическую проводимость фильтрационно-емкостных свойств пород, характеристик структуры порового пространства, смачиваемости. Выполнены теоретические расчеты диапазона изменения удельного электрического сопротивления в условиях терригенных коллекторов различного типа. Обосновано значительное влияние на сопротивление пород показателя смачиваемости поверхности горных пород.

Проведен анализ и сопоставлены различные методики оценки смачиваемости пород по данным керна. Установлено, что наибольшие погрешности в оценках смачиваемости пород связаны с гидрофилизацией поверхности вследствие экстракции керна. Сделан вывод о высоких перспективах использования метода рентгеновской томографии керна как прямого метода визуализации порового пространства при оценке смачиваемости эксплуатационных объектов.

В результате обобщения исследований керна с учетом анализа истории разработки геологический разрез с аномально высокими удельными электрическими сопротивлениями (200 Ом'м и выше) интерпретирован как преимущественно гидрофобный. Разрез со стандартными для терригенных коллекторов показаниями сопротивлений (менее 120 Ом·м) отнесен к гидрофильному типу.

Для визейских объектов (пласты Тл, Бб, Мл) Шершневского месторождения нефти на основе величин сопротивлений проведено районирование по распространению коллекторов различного типа смачиваемости. Схемы распространения гидрофильных и гидрофобных коллекторов для визейских эксплуатационных объектов Соликамской депрессии могут быть использованы при выработке проектных решений как на добывающем, так и на нагнетательном фонде скважин.
\end{abstract}

Igor Yu. Kolychev - Senior Engineer (tel.: +007 9824783 029, e-mail: igorkolychev@gmail.com).

Колычев Игорь Юрьевич - ведущий инженер (тел.: +007 9824783 029, e-mail: igorkolychev@gmail.com). 


\section{Introduction}

The territory of the Solikamsk depression is one of the most important and promising areas of oil production growth in Perm region. High economic prospects of the territory are determined by light oil $\left(\mu_{\mathrm{o}}<3 \mathrm{mPa} \cdot \mathrm{s}\right)$ with satisfactory flow characteristics of formations (around $100 \cdot 10^{-3} \mu \mathrm{m}^{2}$ ). Over the past decade a number of promising deposits has been discovered there which are still at initial stages of operation. According to expert estimates, the potential for new discoveries is also significant $[1,2]$.

Deposits of the Visean age are the main development object in the Solikamsk depression. Reservoirs are represented by sandstones and siltstones. In connection with the location of the territory in the Pre-Urals foreland basin, the rocks have lower capacitance properties because of their epigenetic compaction [3]. Porosity $\left(K_{\mathrm{p}}\right)$ of reservoirs is in the range of 10 to $20 \%$, oil content $\left(K_{\mathrm{o}}\right)$ is in the range of 0.50 to 0.92 .

In general, the reservoirs are characterized by a high heterogeneity in reservoir properties, which complicates the development conditions. According to [4], for the territory of study the success of well workovers and treatment has been estimated in recent years from 44 to $62 \%$. Over a 35 -year period of development of old deposits for this area, significant geological and commercial information and development experience have been accumulated, which require review today. Such a system analysis in the future should positively affect the effectiveness of future workovers and treatment.

\section{Statement of the problem of evaluation of wettability of reservoir saturated with oil using the electrometry data in conditions of a high-resistance geological and geophysical section}

A characteristic feature of the geophysical section of the Visean deposits is the abnormally high specific electrical resistance (SER) of oilsaturated reservoirs, which can significantly exceed $200 \Omega \cdot \mathrm{m}$ (in some cases more $2000 \Omega \cdot \mathrm{m}$ ). Such the phenomenon is extremely rare for clastic rocks. Generalization of well logging of various territories shows that the values of SER for the clastic oil-bearing strata are usually within $5-20 \Omega \cdot \mathrm{m}$ and are almost always limited $40-120 \Omega \cdot \mathrm{m}$ both for the
Perm region [5] and for other territories [6-9]. Oil and gas Bazhenov father set which rock SER can reach $3000 \Omega \cdot \mathrm{m}$ is the rare example, associated with the hydrophobicity of sediments. Hydrophobization of rocks is probably associated with a large proportion of organic material of that deposits, as well as with their thin-layered structure (the thickness of the interlayers is $0.4-0.6 \mathrm{~m}$ ) [10].

Visean beds of the Solikamsk depression studied in the paper are mainly composed with formations of 1 to $3 \mathrm{~m}$ of fine-grained and medium-grained sandstones with a low clay content $\left(\mathrm{K}_{\mathrm{cl}}\right)$ of the order of 1-5. It should be noted that carbonate minerals are characterized by higher hydrophobicity in comparison with quartz [11], therefore in an oil-bearing carbonate section a degree of hydrophobization of reservoir is usually higher than in clastic ones. However, according to the data of [12], for the territory of the Solikamsk depression, on the contrary, clastic reservoirs are more hydrophobic in average $\left(\mathrm{M}_{\mathrm{av}}=0.22\right)$, than carbonate $\left(\mathrm{M}_{\mathrm{av}}=0.31\right)$, while for all other areas of the Perm region the opposite ordinary situation is noted.

It is noteworthy that on the same deposits of the Solikamsk depression in the Visean deposits both the intervals of high-ohm and low-ohm sections are presented. In the author's opinion, high SER are associated with hydrophobization of reservoirs and a low-resistance section is associated with predominantly filiform rocks. Today, oil and gas enterprises do not take into account increased SER. Design is justified without taking into account the nature of wettability of reservoirs. Meanwhile, displacement characteristics for hydro-phobic and hydro-philic reservoirs are fundamentally different.

In general, the state of the surface of rocks affects flooding processes, capillary treatment, formation of current oil content and distribution of residual reserves [13]. On the one hand, water will be much easier to migrate in the hydrophilic formation when pumping is organized. At the initial stages of production before water breakthrough to production wells, the characteristics of oil recovery of hydrophilic reservoirs exceed similar characteristics of hydrophobic ones. However, after the waterflood is organized on the late stages, there is still unrecovered oil in the large pores. According to theoretical concepts, in a predominantly 
hydrophobic formation oil adheres to the pore surface, which increases the chances of continuous flow to the production well. As a result, displaced oil remains on the surface of the pores and in shallow pore channel, which prevents penetration of water into large pores due to capillary forces [14].

Development of Visean reservoirs in the Solikamsk depression goes with the maintenance of reservoir pressure by pumping water into the reservoir, including using non-stationary injection methods, whose effectiveness due to the high heterogeneity of the reservoirs is cinsidered high [15]. At the same time, for some sections of the reservoirs, a sharp decrease in the injectivity was observed in the first month of operation after the workovers and treatment, which is related in [5] with the likely hydrophobization of the section. In general, the problem of delineating the volumes of hydrophobic-type reservoirs is defenetly relevant for the study area. In the future information on the type of reservoir wettability can have practical application in the planning of workovers and treatments both in production and injection wells.

\section{Methods for estimation of wettability of the surface of rocks using core study data}

Wetability indicates the disposition of the solid material to be wetted by a certain liquid in presence of that fluid. The wettability index is not a known characteristic of the rock but depends on the type of wetting liquid and structural energy formation of the oil deposit. Distribution of hydrophobic and hydrophilic sectors, their number and alternation depend on the nature of the rockforming minerals, pore space structure, physical and chemical properties of saturating fluids and residual water content in that [16].

It is known that rock-forming minerals are predominantly wetted by water. So, before the oil migration in them rocks are hydrophilic. Due to long-term contact of oil on the surface of rock-forming minerals, a process of selective adsorption of active oil components occurs. In order for the components of the oil to cause a change in the wettability the oil phase must displace the brine from the surface. Physically, the process of hydrophobization consists in breaking (wedging) of a thin film of residual relic water in the pores. The nature and magnitude of the disjoining pressure is affected by the composition of the oil, as well as the $\mathrm{pH}$ and the composition of the brine [17].

Under natural conditions microstructural wettability is highly heterogeneous at the level of individual pores and capillaries. At the same time some surfaces are in contact with oil, and the water film on them can be unstable. As a result, intervals of low-permeability rocks can remain hydrophilic, while adjacent strata are better wetted with oil. Even in a single sample of the core mixed wettability can be observed with the occurence of different types of surface. Large pores are more likely to be hydrophobic with a mixed wettability character and hydrophilic with small surrounding contact points of grains of the rock [18].

Hydrophobic and hydrophilic types of reservoirs differ in the character of the distribution of water and oil phases in the pore volume of rocks and in dynamics of the process of oil displacement. In conditions of intensive water flooding, an initial equilibrium state of reservoir system is disturbed and wettability of rocks can change, which makes it especially important to estimate the wettability precisely for the deposits developed with a reservoir pressure maintenance system.

A lot of methods and patents for determination of physical and chemical properties of the surface are known (Amotte method, adsorption methods, centrifugation method, capillary pressure curves, isometric drying). Description of the main techniques is considered in the works $[19,20]$.

The methods of capillary pressure and centrifugation are the most widespread in the Perm region [21]. The essence of the method consists in the interdependence of displaced volumes of the hydrocarbon and aqueous phases due to the occurence of capillary forces and hydrodynamic pressure. A quantitative estimate is the wettability parameter $\mathrm{M}$, ranking the rocks on a linear scale from absolutely hydrophobic $(\mathrm{M}=0)$ to hydrophilic $(M=1)$. The indicator $M$ indicates the preference for the rock to be wetted with water and kerosene.

There are attempts in a number of works that have been made to compare results of the wettability evaluation by various methods. Thus, comparison of the indicator $\mathrm{M}$ with the coefficient of hydrophobization $\theta_{0}$, obtained by the isothermal drying method, showed incomplete conformity, but in general a high correlation of the methods [22]. 
At the same time, a comparison of the results of the estimation of $\mathrm{M}$ with the Amott method allowed in [23] to conclude that the Amott method is more informative for samples with selective wettability. In general, analysis of the results of [23] shows an overestimation of the hydrophobicity of the $\mathrm{M}$ estimate in comparison with the Amott method.

The problem of evaluation of wettability in most standard techniques is that the wettability in them is determined already on the extracted core with physical and chemical properties changed as a result of the action of hydrocarbon solvents. In this case, extraction can change the properties of the surface of rocks, mainly towards their hydrophilization [23, 24]. As a result, real reservoir characteristics are violated. The method of nuclear magnetic resonance does not have such drawbacks [25-27], however its use in logging in the Perm region was not widely used.

Summarizing the information from laboratory wettability evaluation data, note that all methods are indirect and their quantitative estimates are often based on different physical processes. The method of X-ray tomography of core, which allows visualizing the structure of pore space of rocks and host fluids, is advantageous from them. The possibilities of this method for estimating the structural space of rocks are given in [28-30]. The characteristic tomograms for hydrophobic and hydrophilic reservoirs are shown in Fig. 1.
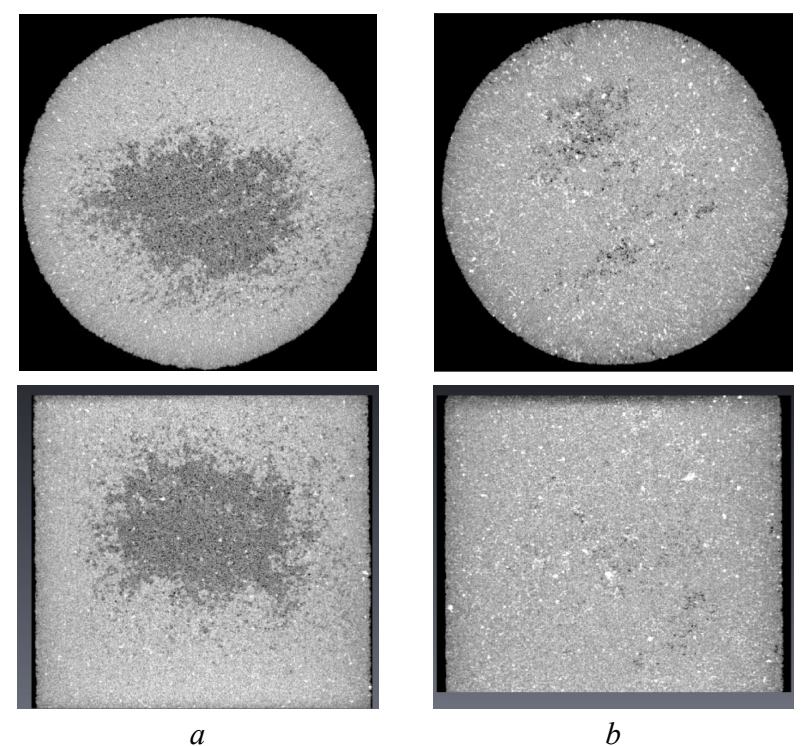

Fig. 1. Tomograms of transverse and longitudinal sections of saturated samples of hydrophobic $(a)$ and hydrophilic $(b)$ reservoirs of Visean deposits of Solikamsk depression
Hydrophobic samples (see Fig. 1a), due to their low wettability are characterized by the smaller penetration of the $\mathrm{NaI}$ solution into the undersaturated central part of the sample (dark gray spot). The entire hydrophilic sample is characterized by complete uniform treatment (see Fig. 1b) [31]. Thus, X-ray tomography allows to visualize in core samples areas with a hydrophobic surface. With this in mind, in the paper the wettability assessments of samples are largely based on results of core tomography.

\section{Evaluation of wettability \\ of rocks using the logging data of electrical methods}

There are regularities of the effect of wettability of a surface on electrical conductivity of the Visean reservoirs determined in the paper [31] based on data of study of core and wells. Let's consider theoretical representations about the influence of characteristics of wettability on indications of SER.

As is known, SER of rocks does not depend on their mineral composition because the rockforming elements (quartz, feldspar etc.) correspond to first-class insulators ( $\rho_{\mathrm{r}}$ from $10^{10}$ to $10^{15} \Omega \cdot \mathrm{m}$ ) [32]. Water resistance $\left(\rho_{\mathrm{w}}\right)$, depending on the concentration, mineralization of salts and temperature, is usually in the range from 0.01 to $1 \Omega \cdot \mathrm{m}$, which is many orders of magnitude less than resistance of the mineral skeleton [33]. In the oil-saturated rock oil that replace the volume of pore space increases the SER. Accordingly, the conductivity of oil-saturated reservoirs is determined by the volume and structure of the pore space occupied by the water phase. Continuity of the water phase in the hydrophobic layer can be disturbed, which leads to an increase in resistivity.

According to theoretical notions, SER of nonclay reservoirs is determined by porosity, water saturation, tortuosity of current-carrying channels, structural coefficient and wettability of rocks. The formula for determination of rock SER can be represented in the following form

$$
\rho_{\mathrm{r}}=\rho_{\mathrm{w}} \cdot T \cdot K_{\mathrm{p}}^{-m} \cdot K_{\mathrm{w}}^{-n},
$$

where $\rho_{\mathrm{w}}$ - resistance of formation water, $\Omega \cdot \mathrm{m}$; $T$ - tortuosity of current-carrying channels; $K_{\mathrm{p}}$ - porosity coefficient, fractions; $K_{\mathrm{w}}-$ water saturation coefficient, fractions; $m-$ structural coefficient; $n$ - wettability index. 
In [34], based on the analysis of the method of sensitive input data [35], it was concluded that for hydrophilic sand reservoirs, the values of SER are most influenced by the coefficient $m$, water saturation and porosity [34]. Calculations of possible values of SER on example of a reservoir $\mathrm{Bb}$ of the Shershnevskoe field for formations with the lowest reservoir properties are performed; at average values of reservoir properties (in accordance with the state balance); with the highest reservir properties. Actual values of reservoir properties and $\rho_{\mathrm{w}}=0,045 \Omega \cdot \mathrm{m}$ were taken from the design document [36].

The sinuosity of current-carrying channels for oil-saturated rocks varies from 1.4 to 2.4 units
[37]. The structural index $m$ for medium-cemented sandstones, according to theoretical and experimental data, varies from 1.5 to 2 [38]. The $T$ and $m$ indices were taken successively as the structure of the pore space became more complicated: $T=1.4$ and $m=1.5 ; T=1.9$ and $m=1.75 ; T=2.4$ and $m=2$.

The most ambiguous is the estimate of the wettability index $n$, which is an integral part of the Archie equation that relates the irreducible water saturation coefficient $K_{\text {i.w }}$ and SER:

$$
P_{\mathrm{o}}=1 /\left(K_{\mathrm{i} . \mathrm{w}}\right)^{n} \text {, }
$$

where the saturation parameter $P_{\mathrm{o}}$ is calculated as the ratio of the SER of the oil-saturated and watersaturated interlayers $P_{\mathrm{o}}=\rho_{\mathrm{o} . \mathrm{i}} / \rho_{\mathrm{w} . \mathrm{i}}$.

Calculation of SER of rocks depending on capacitive and structural characteristics of pore space

\begin{tabular}{|c|c|c|c|c|c|c|c|c|c|}
\hline \multirow{3}{*}{$n$} & \multicolumn{9}{|c|}{$\rho_{\mathrm{r}}, \Omega \cdot \mathrm{m}$} \\
\cline { 2 - 10 } & \multicolumn{3}{|c|}{$K_{\mathrm{p}}=0.106 ; K_{\mathrm{i} . \mathrm{w}}=0.494$} & \multicolumn{2}{c|}{$K_{\mathrm{p}}=0.165 ; K_{\mathrm{i} . \mathrm{w}}=0,104$} & \multicolumn{3}{c|}{$K_{\mathrm{p}}=0.201 ; K_{\text {i.w }}=0.076$} \\
\cline { 2 - 10 } & $\begin{array}{c}T=1.4, \\
m=1.5\end{array}$ & $\begin{array}{c}T=1.9, \\
m=1.75\end{array}$ & $\begin{array}{c}T=2.4, \\
m=2\end{array}$ & $\begin{array}{c}T=1.4, \\
m=1.5\end{array}$ & $\begin{array}{c}T=1.9, \\
m=1.75\end{array}$ & $\begin{array}{c}T=2.4, \\
m=2\end{array}$ & $\begin{array}{c}T=1.4, \\
m=1.5\end{array}$ & $\begin{array}{c}T=1.9 \\
m=1.75\end{array}$ & $\begin{array}{c}T=2.4, \\
m=2\end{array}$ \\
\hline 1.3 & 5 & 11 & 24 & 18 & 38 & 75 & 20 & 40 & 76 \\
\hline 2 & 7 & 18 & 39 & 87 & 185 & 365 & 121 & 245 & 463 \\
\hline 3 & 21 & 36 & 80 & 836 & 1779 & 3526 & 1593 & 3228 & 6090 \\
\hline
\end{tabular}

According to classical sources, $n$ for hydrophilic reservoirs is $1.3-2.0,2.5$ to 5.0 for reservoirs with intermediate wettability and more than 5 for hydrophobic reservoirs [39, 40]. However, it is known that the hydrophobicity of rocks in pure form can be found exclusively in the oil and gas reservoir strata. Thus, it is recommended in [17] to take the values $n>2$ for hydrophilic reservoirs. Taking that into account, as well as the data of [41], the following estimates of the wettability index were adopted in the calculations: for hydrophilic $-n=1.3$ with a transition characteristic of wettability $-n=2$, for hydrophobic $-n=3$. Results of the calculations are tabulated above.

It can be seen from the table that it is the wettability index that affects design values of the SER the most. For hydrophilic rocks, regardless of the SER and pore space structure, SER are limited to $80 \Omega \cdot \mathrm{m}$. For hydrophobic formations with good reservoir properties, in all the cases, the estimates of SER are very large, with intermediate wettability on the SER is more influenced by the structure of the pore space of rocks. For formations with low reservoir properties SER does not exceed $80 \Omega \cdot \mathrm{m}$ even with high wettability values $(n=3)$.
The calculations above, of course, do not characterize all possible real situations of the wettability relationship and SER but reflect the general trend of the process.

\section{Study of spatial distribution of hydrophilic and hydrophobic type reservoirs}

Influence of wettability of rocks on the readings of the SER for Visean reservoirs of the Solikamsk depression is justified above. Accordingly, the geometrization of the zones of development of hydrophobic and hydrophilic reservoirs can be judged from the zonality of the distribution of abnormally high SER of oilsaturated rocks.

For the geophysical section considered in the paper the lateral logging (LL) data are the most reliable in SER assessment. In the high-resistance section the LL has an advantage over conventional electrodes, since even low-density strata under unfavorable conditions $\left(\rho_{\mathrm{o} . \mathrm{i}} / \rho_{\mathrm{w} . \mathrm{i}}\right)$ are clearly distinguished on its logging curves. The data for wells drilled on fresh (clay) drilling fluids $\left(\rho_{\mathrm{w}}>0.3 \Omega \cdot \mathrm{m}\right)$ is considered as suitable for quantitative assessment. 
Analysis of distribution of reservoirs of various types of wettability will be performed using the example of Visean reservoirs of Shershnevskoe field, the development of which is performed at the three production objects of Tulskiy (formation $\mathrm{Tl}$ ), Bobrikovskiy (formation $\mathrm{Bb}$ ) and Radaevskiy (formation $\mathrm{Ml}$ ). The range of changes in porosity of the formations is from 10 to $20 \%$, oil saturation is from 51 to $93 \%$, clay content is low, less than $5 \%$. The formations are characterized by different geological conditions of formation and reservoir properties, therefore the analysis must be carried out for each formation separately.

Reservoirs of formation $\mathrm{Tl}$ (thickness 11-14 m) are represented mainly by medium and finegrained sandstones. Sand layers are relatively isolated from surrounding clayey-silty sediments and often lithologically closed traps. Porosity of Tula sandstones is on average $15.6 \%$, permeability is $273 \cdot 10^{-3} \mu \mathrm{m}^{2}$. The permeability distribution is asymmetric, with the maximum in the range of $250-500 \cdot 10^{-3} \mu \mathrm{m}^{2}[36]$.

Reservoirs of the Bobrikov age (thickness 12-20 m) are represented in the main mass by finegrained and medium-grained aleuritic sandstones. There are zones of increased reservoir thicknesses of up to $16 \mathrm{~m}$ identified in the deposits of the Bobrikov formation. Location of that zones in plan indicates that river flows existed at that time, which on the modern plane was reflected in the form of hose-like shapes of increased thicknesses of the north-western direction. Formation $\mathrm{Bb}$ has good reservoir properties. Mean values of porosity and permeability are $17.4 \%$ and $401 \cdot 10^{-3} \mu \mathrm{m}^{2}$. Permeability distribution is asymmetric, with the maximum in the range of $250-500 \cdot 10^{-3} \mu \mathrm{m}^{2}$ [36].

Rocks of Radayevskiy age (thickness 3-14 m) are unconformably located on the Tournaisian sediments and not presented in erosion zones. Higher values of thickness tend to slope the structure of the reef array and to its lowered sections. Reservoirs are represented by sandstones that are fine-grained, medium-grained. Mean values of porosity and permeability by the core are $14.4 \%$ and $206 \cdot 10^{-3} \mu \mathrm{m}^{2}$. The permeability distribution is asymmetric, with the maximum in the interval of $100-250 \cdot 10^{-3} \mu \mathrm{m}^{2}$ [36].

Thus, reservoir properties of production Visean objects largely differ in the same way as the distribution of effective thicknesses. Considering that, the analysis of the distribution of reservoirs with different types of wettability was carried out separately for reservoirs of $\mathrm{Tl}, \mathrm{Bb}$ and $\mathrm{Ml}$ layers. A fraction of reservoir hydrophobization (the range of variation from 0 to 1 ) is calculated for wells of each layer as a ratio of thicknesses with hydrophobic properties of the surface to the total thickness of oilsaturated reservoirs. Interlayers with thicknesses of at least $0.8 \mathrm{~m}$, for which determination of SER was considered to be close to the true were taken into account in calculations. Intervals of the geological section with SER $>200 \Omega \cdot \mathrm{m}$ were assumed to be hydrophobic, with the SER $<120 \Omega \cdot \mathrm{m}-$ hydrophilic, intervals with intermediate values of SER $(120-200 \Omega \cdot \mathrm{m})$ were excluded from the thickness calculations.

As a result, schemes of distribution of the share of hydrophobic reservoirs for reservoir deposits $\mathrm{Tl}$, $\mathrm{Bb}$ and $\mathrm{Ml}$ were constructed (Fig. 2). At the same time, there are significant differences in distribution of that indicator, which confirms the correctness of separate study of the wettability of Visean objects.

It is seen from the Fig. $2 a$ that a hydrophobic type of reservoirs is distributed in the southern, central and partly northwestern part of the $\mathrm{Tl}$ reservoir. In general, the hydrophilic type adjoins the external oil bearing contact in the east, north and west of the deposit. At the same time, single wells $(240,231)$ close to the aquifer are also referred to the hydrophobic type.

For the formation $\mathrm{Bb}$, the hydrophobic type of reservoir is confined to the central part of the deposit, adjoins the outer oil bearing contour only in the eastern part (see Fig. 2b). The hydrophilic type is found in the areas located near the aquifer. In general, shares of hydrophilic and hydrophobic intervals for $\mathrm{Tl}$ and $\mathrm{Bb}$ formations can be considered comparable. The more far from the aquifer the higher the share of hydrophobic type of reservoirs.

Significant share of zones of reservoirs replaced by dense rocks, which is particularly delineated in its western part (see Fig. 2c) is a distinctive feature of the field of Ml reservoir. Almost all areas adjacent to the wedging of reservoirs are hydrophobic. The site in the southeast of the deposit (area of wells 412, 416) is an exception. Areas close to the outer contour in the southeastern part and fragmentarily in the north of the deposit (area of wells 238, 239), on the contrary, are mainly hydrophilic. In general, there is a feature of the Ml formation reservoir (probably in connection with development of reservoir replacement zones) that hydrophobic reservoir type is predominant (see Fig. 2c). 


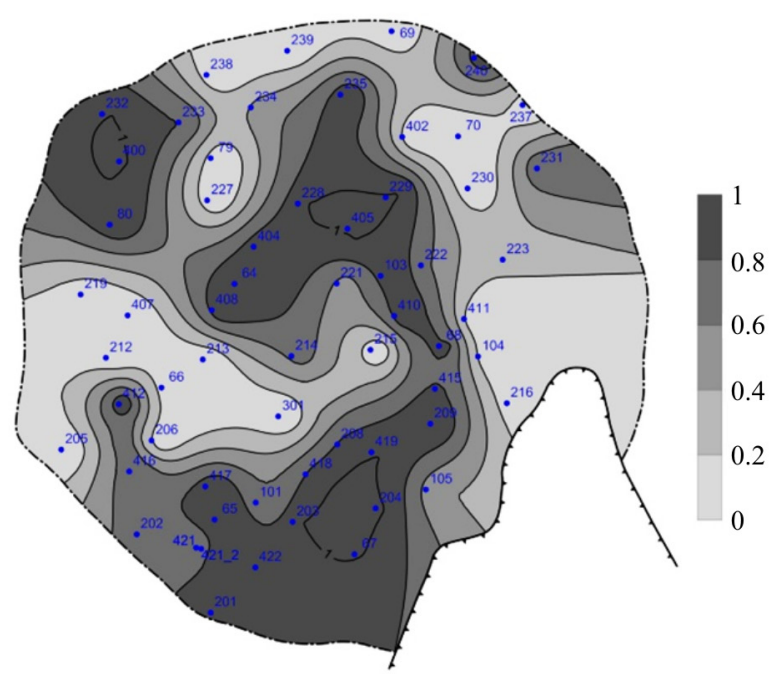

$a$

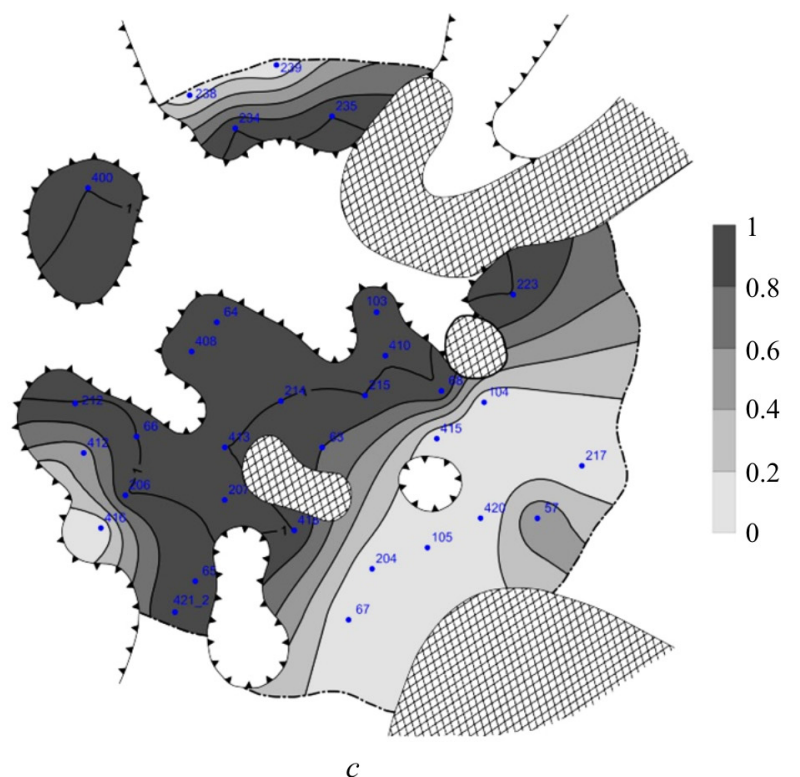

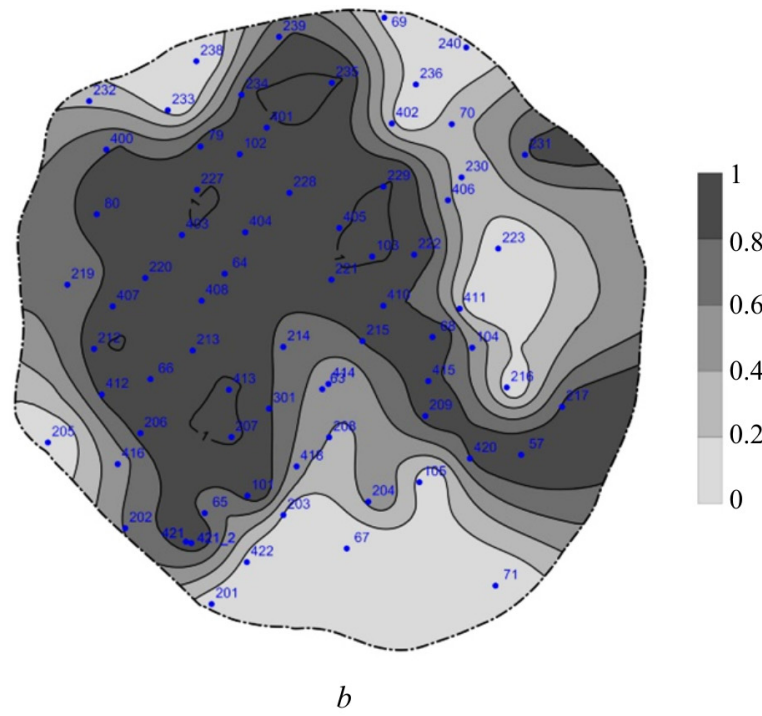

T The border of reservoir replacement zone

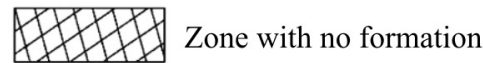

---- External oil bearing contact

Fig. 2. Schemes of distribution of the share of hydrophobic reservoirs for formations deposits $\mathrm{Tl}(a), \mathrm{Bb}(b), \mathrm{Ml}(c)$ of the Shershnevskoe field

Schemes of distribution of mainly hydrophilic and hydrophobic reservoirs for Visean production objects of the Solikamsk depression can be used both in analysis of production characteristics of well sections and in organization of effective injection. In order to develop areas with different wettability characteristics of formations fundamentally different technologies must be adopted. That should be taken into account when organizing effective reservoir operation regimes.

\section{References}

1. Kurchikov A.R., Borodkin V.N., Galkin S.V., Galkin V.I., Rastegaev A.V. Metodika veroiatnostnoi otsenki geologicheskikh riskov pri poiskakh neftianykh mestorozhdenii dlia territorii $\mathrm{s}$ vysokoi plotnost'iu promyshlennykh otkrytii [Some method of probability assessment of geological risks while prospecting for oil fields on territories with high density of commercial discoveries] Geologiia, geofizika i razrabotka neftianykh $i$ gazovykh mestorozhdenii, 2013, no.10, pp.4-13.

2. Galkin S.V. Accounting methods of geological risks on the stage of oil fields exploration. Bulletin of Perm
National Research Polytechnic University. Geology. Oil \& Gas Engineering \& Mining, 2012, vol.11, no.4, pp.23-32.

3. Liadova N.A., Iakovlev Iu.A., Raspopov A.V. Geologiia i razrabotka neftianykh mestorozhdenii Permskogo kraia [Geology and development of oil deposits of the Perm region]. Moscow, VNIIOENG, 2010, $335 \mathrm{p}$.

4. Iliushin P.Iu., Rakhimzianov R.M., Solov'ev D.Iu., Kolychev I.Iu. Analysis of well intervention aimed at oil production enhancement in the Perm krai's fields. Bulletin of Perm National Research Polytechnic University. 
Geology. Oil \& Gas Engineering \& Mining, 2015, vol.14, no.15, pp.81-89. DOI: 10.15593/2224-9923/2015.15.9

5. Soboleva E.V., Efimov A.A., Galkin S.V. Analiz geologo-geofizicheskikh kharakteristik terrigennykh kollektorov pri prognoze priemistosti skvazhin mestorozhdenii Solikamskoi depressii [The analysis of geological and geophysical characteristics of terrigenous reservoirs at the forecast injectability of wells of Solikamskaya depression]. Neftianoe khoziaistvo, 2014, no.6, pp.20-22.

6. Iskenderov M.M. Kompleksnaia interpretatsiia rezul'tatov GIS pri izuchenii terrigennykh razrezov [Integrated interpretation of well logging results in the study of terrigeneous sections]. Nauchnye trudy NIPI Neftegaz GNKAR, 2014, no. 3, pp.4-10. DOI: 10.5510/OGP20140300204

7. Petrov A.M., Sukhorukova K.V., Nechaev O.V. Opredelenie anizotropii udel'nogo elektricheskogo soprotivleniia vysokoomnykh otlozhenii po dannym bokovogo karotazhnogo zondirovaniia [Determination of the anisotropy of the resistivity of high-resistivity deposits from lateral logging]. Interekspo Geo-Sibir', 2016, vol.2, no.1, pp.227-231.

8. Nikiforova O.G. Otsenka udel'nogo elektricheskogo soprotivleniia i kharaktera nasyshchennosti nizkoomnykh terrigennykh kollektorov po dannym GIS [Estimation of the specific electrical resistance and the nature of the saturation of low-resistance clastic reservoirs according to geophysics data]. Geofizika, 2008, no.1, pp.22-24.

9. Shilanov N.S., Khibasov B.B., Baitenov K.S. Osobennosti interpretatsii materialov karotazha po novym skvazhinam [Features of interpretation of logging materials for new wells]. Nauchnye trudy NIPI Neftegaz GNKAR, 2011, no.3, pp.16-19. DOI: 10.5510/OGP20110300073

10. Kuliapin P.S., Sokolova T.F. Ispol'zovanie statisticheskogo modelirovaniia pri interpretatsii dannykh GIS v neftematerinskikh porodakh bazhenovskoi svity Zapadno-Sibirskoi neftegazonosnoi provintsii [Use of statistical modeling in interpretation of geophysics data in the oil-bearing rocks of the Bazhenov suite of the West Siberian oil and gas province]. Tekhnologii seismorazvedki, 2013, no.3, pp.28-42.

11. Mitrofanov V.P., Ermakova M.I. Smachivaemost' produktivnykh otlozhenii iugo-vostochnoi chasti Permskogo regiona [Wetability of productive deposits of the southeastern part of the Perm Region]. Geologiia, geofizika $i$ razrabotka neftianykh $i$ gazovykh mestorozhdenii, 2009, no.1, pp.29-32.

12. Zlobin A.A., Iushkov I.R. O mekhanizme gidrofobizatsii poverkhnosti porod-kollektorov nefti i gaza [On the mechanism of hydrophobization of the surface of the reservoir rocks of oil and gas]. Vestnik Permskogo universiteta. Geologiia. 2014, no.3 (24), pp.68-79.

13. Nesterenko N.Iu. Vliianie smachivaemosti poverkhnosti na razdelenie nefti $\mathrm{v}$ porode [Influence of surface wettability on the oil separation in the rock]. Geologiia nefti i gaza, 1994, no.8, pp.28-32.

14. Anderson W.G. Wettability literature survey. Part 4: Effects of wettability capillary pressure. Journal of Petroleum Technology, 1987, vol. 39, pp.1283-1300. DOI: 10.2118/15271-PA
15. Chumakov G.N., Zotikov V.I., Kolychev I.Iu., Galkin S.V. Analiz effektivnosti primeneniia tsiklicheskoi zakachki zhidkosti na mestorozhdeniiakh s razlichnymi geologo-tekhnologicheskimi usloviiami [Analysis of the effectiveness of cyclic fluid injection at fields with different geological and technological conditions]. Neftianoe khoziaistvo, 2014, no.9, pp.96-99.

16. Mikhailov N.N., Motorova K.A., Sechina L.S. Geologicheskie faktory smachivaemosti porod-kollektorov nefti i gaza [Geological factors of wettability of reservoir rocks of oil and gas]. Neftegas.ru, 2016, no.3, pp.80-90.

17. Abdalla V., Bakli D.S., Karnegi E., Edvards D., Kherol'd B., Fordem E., Graue A., Khabashi T., Seleznev N., Sin'er K., Khusein Kh., Montaron B., Ziauddin M. Osnovy smachivaemosti [Basics of wettability]. Neftegazovoe obozrenie, 2007, vol.19, no.2, pp.54-75.

18. Kovscek A.R., Wong H., Radke C.J. A pore level scenario for the development of mixed wettability in oil reservoirs. American Institute of Chemical Engineers, 1993, 39, no.6, pp.1072-1085. DOI: 10.2118/24880-MS

19. Dixit A.B., Buckley J.S., McDougall S.R., Sorbie K.S. Empirical measures of wettability in porous media and the relationship between them derived from pore-scale modeling. Transp. Porous Media, 2000, vol.40, iss.1, pp.27-54. DOI: 10.1023/A:1006687829177

20. Nesterenko N.Iu. Smachivaemost' porod-kollektorov plastovymi fliuidami [Wetability of reservoir rocks by reservoir fluids]. Geologiia nefti i gaza, 1995, no.5.

21. OST 39-181-85. Neft'. Metod opredeleniia smachivaemosti uglevodorodsoderzhashchikh porod [Oil. Method for determination of wettability of hydrocarbonaceous rocks], available at: http:/gostrf.com/ normadata/1/ 4293835/4293835425.pdf (accessed: 12 June 2017).

22. Mikhailov N.N., Sechina L.S., Gurbatova I.P. Pokazateli smachivaemosti $\mathrm{v}$ poristoi srede i zavisimost' mezhdu nimi [The wettability indexes in a porous medium and the relationship between them]. Aktual'nye problemy nefti $i$ gaza, 2011, no.1 (3), p.10.

23. Gurbatova I.P., Melekhin S.V., Chizhov D.B., Fairuzova Iu.V. Features of study complex carbonate reservoir rocks` wetting using laboratory methods. Bulletin of Perm National Research Polytechnic University. Geology. Oil \& Gas Engineering \& Mining, 2016, vol.15, no.20, pp.240-245. DOI: 10.15593/2224-9923/2016.20.4

24 Xizhnyak G.P., Amirov A.M., Mosheva A.M., Melexin S.V., Chizhov D.B. Influence of wettability on oil displacement efficiency. Bulletin of Perm National Research Polytechnic University. Geology. Oil \& Gas Engineering \& Mining, 2013, vol.12, no.6, pp.54-63.

25. Zlobin A.A., Iushkov I.R. Opredelenie smachivaemosti poverkhnosti porovykh kanalov neekstragirovannykh porod-kollektorov [Determination of the wettability of the surface of pore channels of nonextracted reservoir rocks]. Geologiia, geofizika $i$ razrabotka neftianykh $i$ gazovykh mestorozhdenii, 2009, no.10, pp.29-32.

26. Allen D., Flaum C., Ramakrishnan T.S., Bedford J., Castelijns K., Fairhurst D., Gubelin G., Heaton N., Minh C.C., Norville M.A., Seim M.R., Pritchard T., 
Ramamoorthy R. Trends in NMR logging. Oilfield Review, 2000, 12, no.3, pp.2-19.

27. Chen J., Hirasaki G.J., Flaum M. NMR wettability indices: effect of OBM on wettability and NMR responses. Journal of Petroleum Science and Engineering, 2006, 52, no.1-4, pp.161-171. DOI: 10.1016/j.petrol.2006.03.007

28. Galkin S.V., Efimov A.A., Krivoshchekov S.N., Savitskiy Ya.V., Cherepanov S.S. X-ray tomography in petrophysical studies of core samples from oil and gas fields. Russian Geology and Geophysics, 2015, no.5, pp.782-792. DOI: 10.1016/j.rgg.2015.04.009.

29. Alemu B.L., Aker E., Soldal M., Johnsen O., Aagard P. Effect of sub-core scale heterogeneities on acoustic and electrical properties of a reservoir rock: a $\mathrm{CO}_{2}$ flooding experiment of brine saturated sandstone in a computed tomography scanner. European Association of Geoscientists \& Engineers. Geophysical Prospecting, 2012, 61, pp.235250. DOI: $10.1111 / \mathrm{j} .1365-2478.2012 .01061 . \mathrm{x}$

30. Efimov A.A., Galkin S.V., Savitckii Ia.V., Galkin V.I. Estimation of heterogeneity of oil \& gas field carbonate reservoirs by means of computer simulation of core x-ray tomography data. Ecology, Environment and Conservation, 2015, vol.21, pp.79-85.

31. Efimov A.A., Savitskii Ia.V., Galkin S.V., Soboleva E.V., Gurbanov V.Sh. Issledovanie smachivaemosti kollektorov neftianykh mestorozhdenii metodom rentgenovskoi tomografii kerna [Investigation of wettability of reservoirs of oil deposits by the method of X-ray tomography of core]. Nauchnye trudy NIPI Neftegaz GNKAR, 2016, vol.4, no.4, pp.55-63. DOI: 10.5510/OGP20160400298

32. Itenberg S.S., Dakhkil'gov T.D. Geofizicheskie issledovaniia $\mathrm{V}$ skvazhinakh [Geophysical studies in wells]. Moscow, Nedra, 1982, 351 p.

33. Koskov V.N., Koskov B.V. Geofizicheskie issledovaniia skvazhin i interpretatsiia dannykh GIS [Geophysical studies of wells and interpretation of GIS data]. Perm', 2007, 317 p. Seriia Prioritetnye natsional'nye proekty "Obrazovanie".

34. Iskenderov M.M. Nekotorye rezul'taty modelirovaniia udel'nogo elektricheskogo soprotivleniia (na primere mestorozhdenii Iuzhno-Absheronskoi akvatorial'noi zony i severnoi chasti Bakinskogo arkhipelaga) [Some Results of Modeling Electrical Resistivity (on the Example of Deposits of the SouthAbsheron Aquatorium Zone and the Northern Part of the Baku Archipelago)]. Nauchnye trudy NIPI Neftegaz GNKAR, 2017, vol.2, no.2, pp.4-12. DOI: 10.5510/OGP20170200310

35. Hill T., Lewicki P. Statistics: methods and applications: A comprehensive reference for science, industry, and data mining. Tulsa, OK, StatSoft, 2006. DOI: 10.1016/B978-0-323-03707-5.50024-3

36. Geologicheskoe stroenie i pereschet zapasov uglevodorodnogo syr'ia Shershnevskogo mestorozhdeniia nefti na osnove geologicheskoi modeli [Geological structure and recalculation of hydrocarbon reserves of the Shershnev oil field on the basis of a geological model]. Perm', PermNIPIneft', 2010.

37. Buriakovskii L.A., Dzhafarov I.S., Dzhevanshir R.D. Prognozirovanie fizicheskikh svoistv kollektorov i pokryshek nefti i gaza [Forecasting the physical properties of oil and gas collectors and tires]. Moscow, Nedra, 1982, $200 \mathrm{p}$.

38. Dakhnov V.N. Geofizicheskie metody opredeleniia kollektorskikh svoistv i neftegazonasyshcheniia gornykh porod [Geophysical methods for determining reservoir properties and oil and gas saturation of rocks]. Moscow, Nedra, 1985, $310 \mathrm{p}$

39. Debrant $\mathrm{R}$. Teoriia i interpretatsiia rezul'tatov geofizicheskikh metodov issledovaniia skvazhin [Theory and interpretation of the results of geophysical methods of well investigation]. Moscow, Nedra, 1972, 288 p.

40. Abasov M.T., Aliiarov R.Iu., Kondrushkin Iu.M., Musaev R.A., Gashimov A.F., Lunina V.N., Gasymov A.Sh., Adygezalova A.A. Smachivaemost' porod-kollektorov v protsesse razrabotki zalezhei nefti [Wetability of reservoir rocks during the development of oil deposits]. Neftianoe khoziaistvo, 2004, no.8, pp.69-71.

41. Montaron B. A quantitative model for the effect of wettability on the conductivity of porous rocks. $15^{\text {th }}$ Middle East Oil and Gas Show and Conference, Bahrain, 2007. DOI: 10.2118/105041-MS

\section{Библиографический список}

1. Методика вероятностной оценки геологических рисков при поисках нефтяных месторождений для территорий с высокой плотностью промышленных открытий / А.Р. Курчиков, В.Н. Бородкин, С.В. Галкин, В.И. Галкин, А.В. Растегаев // Геология, геофизика и разработка нефтяных и газовых месторождений. 2013. - № 10. - C. 4-13.

2. Галкин С.В. Методология учета геологических рисков на этапе поисков и разведки нефтяных месторождений // Вестник Пермского национального исследовательского политехнического университета. Геология. Нефтегазовое и горное дело. - 2012. - Т. 11, № 4. - С. 23-32.

3. Лядова Н.А., Яковлев Ю.А., Распопов А.В. Геология и разработка нефтяных месторождений Пермского края. - М.: ВНИИОЭНГ, 2010. - 335 с.
4. Илюшин П.Ю., Рахимзянов Р.М., Соловьев Д.Ю., Колычев И.Ю. Анализ проведения геолого-технических мероприятий по увеличению продуктивности добывающих скважин на нефтяных месторождениях Пермского края // Вестник Пермского национального исследовательского политехнического университета. Геология. Нефтегазовое и горное дело. - 2015. - Т. 14, № 15. - С. 81-89. DOI: 10.15593/2224-9923/2015.15.9

5. Соболева Е.В., Ефимов А.А., Галкин С.В. Анализ геолого-геофизических характеристик терригенных коллекторов при прогнозе приемистости скважин месторождений Соликамской депрессии // Нефтяное хозяйство. - 2014. - № 6. - С. 20-22.

6. Искендеров М.М. Комплексная интерпретация результатов ГИС при изучении терригенных разрезов // 
Научные труды НИПИ Нефтегаз ГНКАР. - 2014. № 3. - C. 4-10. DOI: 10.5510/OGP20140300204

7. Петров А.М., Сухорукова К.В., Нечаев О.В. Определение анизотропии удельного электрического сопротивления высокоомных отложений по данным бокового каротажного зондирования // Интерэкспо Гео-Сибирь. - 2016. - Т. 2, № 1. - С. 227-231.

8. Никифорова О.Г. Оценка удельного электрического сопротивления и характера насыщенности низкоомных терригенных коллекторов по данным ГИС // Геофизика. - 2008. - № 1. - С. 22-24.

9. Шиланов Н.С., Хибасов Б.Б., Байтенов К.С. Особенности интерпретации материалов каротажа по новым скважинам // Научные труды НИПИ Нефтегаз ГНКАР. - 2011. - № 3. - C. 16-19. DOI: 10.5510/OGP20110300073

10. Куляпин П.С., Соколова Т.Ф. Использование статистического моделирования при интерпретации данных ГИС в нефтематеринских породах баженовской свиты Западно-Сибирской нефтегазоносной провинции // Технологии сейсморазведки. - 2013. - № 3. - С. 28-42.

11. Митрофанов В.П., Ермакова М.И. Смачиваемость продуктивных отложений юго-восточной части Пермского региона // Геология, геофизика и разработка нефтяных и газовых месторождений. - 2009. - № 1. C. $29-32$

12. Злобин А.А., Юшков И.Р. О механизме гидрофобизации поверхности пород-коллекторов нефти и газа // Вестник Пермского университета. Геология. - 2014. - № 3 (24). - С. 68-79.

13. Нестеренко Н.Ю. Влияние смачиваемости поверхности на разделение нефти в породе // Геология нефти и газа. - 1994. - № 8. - С. 28-32.

14. Anderson W.G. Wettability literature survey. Part 4: Effects of wettability capillary pressure // Jornal of Petroleum Technology. - 1987. - Vol. 39. - P. 12831300. DOI: $10.2118 / 15271-\mathrm{PA}$

15. Анализ эффективности применения циклической закачки жидкости на месторождениях с различными геолого-технологическими условиями / Г.Н. Чумаков, В.И. Зотиков, И.Ю. Колычев, С.В. Галкин // Нефтяное хозяйство. - 2014. - № 9. - С. 96-99.

16. Михайлов Н.Н., Моторова К.А., Сечина Л.С. Геологические факторы смачиваемости пород коллекторов нефти и газа // Деловой журнал Neftegas.ru. - 2016. - № 3. - С. 80-90.

17. Основы смачиваемости / В. Абдалла, Д.С. Бакли, Э. Карнеги, Д. Эдвардс, Б. Херольд, Э. Фордэм, А. Грауэ, Т. Хабаши, Н. Селезнев, К. Синьер, Х. Хусейн, Б. Монтарон, М. Зиауддин // Нефтегазовое обозрение. 2007. - T. 19, № 2. - C. 54-75.

18. Kovscek A.R., Wong H., Radke C.J. A pore level scenario for the development of mixed wettability in oil reservoirs // American Institute of Chemical Engineers Journal. - 1993. - 39, № 6. - P. 1072-1085. DOI: 10.2118/24880-MS

19. Empirical measures of wettability in porous media and the relationship between them derived from pore-scale modelling / A.B. Dixit, J.S. Buckley, S.R. McDougall,
K.S. Sorbie // Transp. Porous Media. - 2000. - Vol. 40, iss. 1. - P. 27-54. DOI: 10.1023/A:1006687829177

20. Нестеренко Н.Ю. Смачиваемость породколлекторов пластовыми флюидами // Геология нефти и газа. - 1995. - № 5.

21. ОСТ 39-181-85. Нефть. Метод определения смачиваемости углеводородсодержащих пород [Электронный pecypc]. - URL: http:/gostrf.com/ normadata/ 1/4293835/4293835425.pdf (дата обращения: 12.06.2017).

22. Михайлов Н.Н., Сечина Л.С., Гурбатова И.П. Показатели смачиваемости в пористой среде и зависимость между ними // Актуальные проблемы нефти и газа. - 2011. - № 1 (3). - С. 10.

23 Особенности изучения смачиваемости сложнопостроенных карбонатных пород-коллекторов лабораторными методами / И.П. Гурбатова, С.В. Мелехин, Д.В. Чижов, Ю.В. Файрузова // Вестник Пермского национального исследовательского политехнического университета. Геология. Нефтегазовое и горное дело. - 2016. - Т. 15, № 20. - С. 240-245. DOI: $10.15593 / 2224-9923 / 2016.20 .4$

24. Влияние смачиваемости на коэффициент вытеснения нефти / Г.П. Хижняк, А.М. Амиров, А.М. Мошева, С.В. Мелехин, Д.Б. Чижов // Вестник Пермского национального исследовательского политехнического университета. Геология. Нефтегазовое и горное дело. 2013. - T. 12, № 6. - С. 54-63.

25. Злобин А.А., Юшков И.Р. Определение смачиваемости поверхности поровых каналов неэкстрагированных пород-коллекторов // Геология, геофизика и разработка нефтяных и газовых месторождений. - 2009. - № 10. - С. 29-32.

26. Trends in NMR logging / D. Allen, C. Flaum, T.S. Ramakrishnan, J. Bedford, K. Castelijns, D. Fairhurst, G. Gubelin, N. Heaton, C.C. Minh, M.A. Norville, M.R. Seim, T. Pritchard, R. Ramamoorthy // Oilfield Review. - 2000. - 12, № 3. - P. 2-19.

27. Chen J., Hirasaki G.J., Flaum M. NMR wettability indices: effect of OBM on wettability and NMR responses // Journal of Petroleum Science and Engineering. - 2006. - 52, № 1-4. - P. 161-171. DOI: 10.1016/j.petrol.2006.03.007

28. X-ray tomography in petrophysical studies of core samples from oil and gas fields / S.V. Galkin, A.A. Efimov, S.N. Krivoshchekov, Ya.V. Savitskiy, S.S. Cherepanov // Russian Geology and Geophysics. - 2015. - № 5. - P. 782792. DOI: 10.1016/j.rgg.2015.04.009

29. Effect of sub-core scale heterogeneities on acoustic and electrical properties of a reservoir rock: a $\mathrm{CO}_{2}$ flooding experiment of brine saturated sandstone in a computed tomography scanner / B.L. Alemu, E. Aker, M. Soldal, O. Johnsen, P. Aagard // European Association of Geoscientists \& Engineers. Geophysical Prospecting. - 2012. - 61. P. 235-250. DOI: 10.1111/j.1365-2478.2012.01061.x

30. Estimation of heterogeneity of oil \& gas field carbonate reservoirs by means of computer simulation of core x-ray tomography data / A.A. Efimov, S.V. Galkin, Ia.V. Savitckii, V.I. Galkin // Ecology, Environment and Conservation. - 2015. - Vol. 21. - P. 79-85. 
31. Исследование смачиваемости коллекторов нефтяных месторождений методом рентгеновской томографии керна / А.А. Ефимов, Я.В. Савицкий, С.В. Галкин, Е.В. Соболева, В.Ш. Гурбанов // Научные труды НИПИ Нефтегаз ГНКАР. - 2016. - Т. 4, № 4. C. 55-63. DOI: 10.5510/OGP20160400298

32. Итенберг С.С., Дахкильгов Т.Д. Геофизические исследования в скважинах: учеб. для вузов. - М.: Недра, 1982. - 351 с.

33. Косков В.Н., Косков Б.В. Геофизические исследования скважин и интерпретация данных ГИС. Пермь, 2007. - 317 с. (Сер.: Приоритетные национальные проекты «Образование»).

34. Искендеров М.M. Некоторые результаты моделирования удельного электрического сопротивления (на примере месторождений Южно-Абшеронской акваториальной зоны и северной части Бакинского архипелага) // Научные труды НИПИ Нефтегаз ГНКАР. 2017. - T. 2, № 2. - C. 4-12. DOI: 10.5510/OGP20170200310

35. Hill T., Lewicki P. Statistics: methods and applications: a comprehensive reference for science, industry, and data mining. - Tulsa, OK: StatSoft, 2006. DOI: 10.1016/B978-0-323-03707-5.50024-3
36. Геологическое строение и пересчет запасов углеводородного сырья Шершневского месторождения нефти на основе геологической модели / ПермНИПИнефть. - Пермь, 2010.

37. Буряковский Л.А., Джафаров И.С., Джеваншир Р.Д. Прогнозирование физических свойств коллекторов и покрышек нефти и газа. - М.: Недра, 1982. - 200 с.

38. Дахнов В.Н. Геофизические методы определения коллекторских свойств и нефтегазонасыщения горных пород. - М.: Недра, 1985. - 310 с.

39. Дебрант. Р. Теория и интерпретация результатов геофизических методов исследования скважин. - М.: Недра, 1972. - 288 с.

40. Смачиваемость пород-коллекторов в процессе разработки залежей нефти / М.Т. Абасов, Р.Ю. Алияров, Ю.М. Кондрушкин, Р.А. Мусаев, А.Ф. Гашимов, В.Н. Лунина, А.Ш. Гасымов, А.А. Адыгезалова // Нефтяное хозяйство. - 2004. - № 8. - С. 69-71.

41. Montaron B. A quantitative model for the effect of wettability on the conductivity of porous rocks // 15th Middle East Oil and Gas Show and Conference, March 11-14, Bahrain, 2007. DOI: $10.2118 / 105041-\mathrm{MS}$

Please cite this article in English as:

Kolychev I.Yu. Study of zones of wettability distribution based on lateral logging for oil-bearing Visean reservoirs of the Solikamsk depression. Perm Journal of Petroleum and Mining Engineering, 2017, vol.16, no.4, pp.331-341. DOI: 10.15593/2224-9923/2017.4.4

Просьба ссылаться на эту статью в русскоязычных источниках следующим образом:

Колычев И.Ю. Изучение зональности распределения показателей смачиваемости по данным бокового каротажа для нефтенасыщенных визейских коллекторов Соликамской депрессии // Вестник Пермского национального исследовательского политехнического университета. Геология. Нефтегазовое и горное дело. - 2017. - Т.16, №4. - C.331-341. DOI: 10.15593/2224-9923/2017.4.4 